
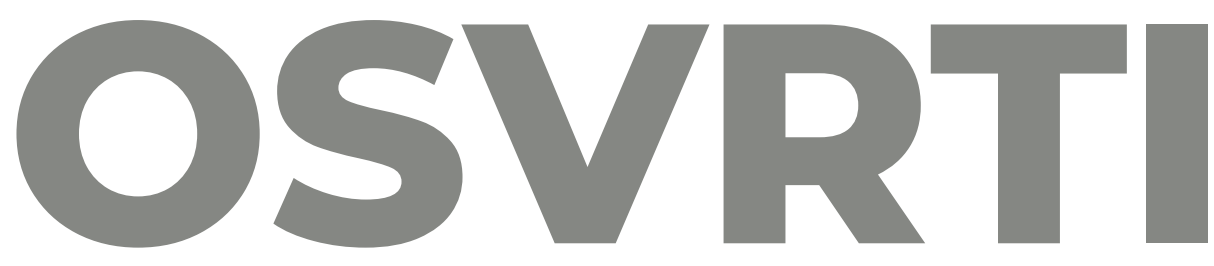

Instituta za javne financije

\title{
Funkcionalna i održiva lokalna samouprava u Nacionalnom planu oporavka i otpornosti 2021. - 2026.
}

\section{Katarina Ott}

Institut za javne financije, Zagreb

Vlada je napravila plan oporavka države koji predviđa i reformu lokalne samouprave. Europska unija (EU) je taj plan podržala i spremna ga je financirati. Plan svakako treba pozdraviti, jer u državi s brojnim lokalnim jedinicama koje imaju izrazito mali broj stanovnika i vrlo niske prihode, odavno se očekuje njihovo ne samo funkcionalno, već i stvarno spajanje. No, kako je takvih planova i projekata već bilo, a nisu se uspijevali realizirati, neophodno je što prije definirati ono čega u ovom planu nema, a to su čvrsti rokovi provedbe svih planiranih podfaza i usluga. Valja se nadati da će ministarstva i druga tijela državne uprave to urgentno i učiniti, te u suradnji s lokalnim jedinicama i drugim kompetentnim dionicima učiniti sve što je potrebno ne samo za povlačenje predviđenih financijskih sredstava, 
već i za njihovo učinkovito korištenje. Jedino tako bi ovaj plan mogao pridonijeti da konačno živimo u državi s funkcionalnom i održivom lokalnom samoupravom. ${ }^{1}$

U okviru Mehanizma za oporavak i otpornost, Vijeće EU-a je odobrilo hrvatski Nacionalni plan oporavka i otpornosti 2021. - 2026. (u daljnjem tekstu Plan) težak 6,3 mlrd. eura, pri čemu se do kraja 2021. može očekivati predujam od oko 6,1 mlrd. kn, odnosno 13\% od ukupno osiguranih bespovratnih sredstava. Isplata će se, naravno, temeljiti na pokazateljima izvršenja rezultata definiranih Planom. Vlada je stoga zadužila „sva nadležna tijela da intenziviraju rad na provedbi aktivnosti i implementaciji" Plana.

U Planu se kao preduvjet provedbe i iskorištavanja predviđenih sredstava navodi podizanje učinkovitosti države u realizaciji reformi i projekata financiranih iz EU-a, te se, između ostaloga, predviđa daljnja decentralizacija države, uz poticanje funkcionalnog spajanja lokalnih jedinica. U okviru dijela Javna uprava, pravosuđe i državna imovina predviđa se daljnje unaprjeđenje učinkovitosti javne uprave, a među reformama su funkcionalna i održiva lokalna samouprava i predviđene investicije za daljnju optimizaciju i decentralizaciju poticanjem funkcionalnog spajanja jedinica.

' Ovaj je osvrt nastao u okviru projekta „Isplati li se transparentnost? Politički i socioekonomski učinci transparentnosti proračuna lokalnih jedinica u Hrvatskoj" (IP-2019-04-8360) koji financira Hrvatska zaklada za znanost (HRZZ). 


\section{Reforme u smjeru funkcionalne i održive lokalne samouprave}

Zbog nezadovoljavajuće razine kvalitete usluga, slabog

administrativnog i fiskalnog kapaciteta te nedostatka

transparentnosti, cilj je funkcionalnim povezivanjem lokalnih jedinica uspostaviti učinkovite, kvalitetne i transparentne usluge, kako bi građani bez obzira gdje žive imali jednake mogućnosti zadovoljavanja svojih potreba i interesa.

Planira se uspostava sustava za financiranje zajedničkog obavljanja pojedinih poslova kako bi se suradnjom lokalnih jedinica lakše prevladavali problemi nedostatnih kapaciteta, unaprijedile usluge i učinkovitost korištenja sredstava. Osnovat će se međuresorna radna skupina stručnjaka tijela državne uprave za podršku zainteresiranim lokalnim jedinicama, izmijenit će se zakonodavni okvir i uspostaviti mehanizam financijske potpore za poticanje funkcionalnog i stvarnog spajanja.

Nositelji provedbe Plana su Ministarstvo pravosuđa i uprave i Ministarstvo financija u suradnji s tijelima državne uprave. Ciljna skupina su lokalne jedinice, krajnji korisnici građani i poslovni subjekti, predviđeni iznos je 21,6 mil. kn, a razdoblje provedbe od prosinca 2021. do lipnja 2025. U odnosu na brojne druge stavke Plana, to nije neki veći iznos, no nije ni zanemariv, pa bi svakako trebalo učiniti sve da ga se što bolje iskoristi.

\section{Optimizacija i decentralizacija poticanjem funkcionalnog spajanja}

Uslijed nedostatnog administrativnog i fiskalnog kapaciteta za pružanje kvalitetnih usluga i zbog posljedičnog nezadovoljstva 
građana, cilj je uspostaviti sustav za funkcionalno i stvarno povezivanje radi što kvalitetnijeg i transparentnijeg pružanja usluga građanima te jačanja kapaciteta za učinkovitije obavljanje poslova lokalnih jedinica.

Definirane su faze i podfaze provedbe te usluga koje će trebati financirati, no rokovi su nažalost utvrđeni samo za faze, ali ne i za podfaze provedbe i predviđene usluge, prikazane u dodatku na kraju teksta. Nije poznato do kada će se, primjerice, trebati izraditi upitnik za samoprocjenu kapaciteta, idejno rješenje i funkcionalne specifikacije sustava podrške spajanju, dijagnostičko izvješće ili kada će se provoditi terensko ispitivanje stanovništva, podizanje svijesti o funkcionalnom spajanju i sl.

Ako se prilagodba propisa do prosinca 2021. i aktivacija mehanizma do ožujka 2022. i mogu smatrati realistično predviđenim rokovima, vrlo je upitno i zabrinjavajuće čekanje smjernica/preporuka do prosinca 2023. i uspostave cjelovitog sustava do lipnja 2025. bez poznavanja unaprijed utvrđenih rokova svih navedenih podfaza i usluga. Istina, spominje se mogućnost vrednovanja plana na sredini provedbe 2024. u okviru „Nacionalnog plana razvoja javne uprave 2021. - 2027. (u izradi)", no to je za praćenje, kontrolu i eventualne korekcije realizacije Plana prekasno, posebice imajući na umu da je Nacionalni plan razvoja javne uprave tek u izradi, a Vlada je odluku o pokretanju njegove izrade donijela tek nedavno (8. travnja 2021.).

Dodatni razlog za zabrinutost izaziva činjenica što se u Planu na više mjesta spominje kako će mu kao podloga poslužiti rezultati projekta Ministarstva uprave „Optimizacija sustava lokalne i područne (regionalne) samouprave“. Naravno, dobro je da se ne kreće svaki put iznova od nule i da se namjeravaju koristiti rezultati 
već provedenih projekata, no što znamo o tom prethodnom projektu? Na mrežnoj stranici Ministarstva uprave stoji da je riječ o projektu vrijednom 20,1 mil. kn, koji će se provesti od 11. prosinca 2018. do 11. prosinca 2020., s ciljem „unaprjeđenja učinkovitosti sustava javne uprave kroz optimizaciju sustava lokalne i područne (regionalne) samouprave što bi rezultiralo povećanjem kvalitete javnih usluga koje se pružaju građanima u jedinicama lokalne i područne (regionalne) samouprave." Prema tome bi taj projekt već trebao biti završen, no javno dostupnih službenih informacija o njegovoj izradi i rezultatima - nema. Kako je očito riječ o projektu sličnog sadržaja, pa i vrlo slične financijske težine (21,6 naspram 20,1 mil. kn), koji je već trebao biti završen, a provedba Plana bi se na njega trebala osloniti, javnosti bi trebali biti poznati rezultati tog projekta.

Kako je jedan od ciljeva Plana i povećanje transparentnosti sustava lokalne i područne (regionalne) samouprave, neophodno je i povećanje transparentnosti sustava središnje države. Sve to zahtijeva urgentnu objavu rezultata spomenutog projekta optimizacije, te rokova svih podfaza i usluga predviđenih Planom, uz redovito praćenje pridržavanja tih rokova i objava rezultata tog praćenja, odnosno rezultata svih podfaza i usluga.

Sâm Plan je vrlo opsežan dokument (1273 stranice), a vjerojatno će ga pratiti barem još toliko stranica pratećih dokumenata, pa je teško očekivati da će se neki veći broj ljudi lako u tome svemu snalaziti, čak i ako budu pokušali pratiti samo pojedine dijelove Plana. Osobito je upitno koliko i kako će se s time upoznati oni za koje bi bilo najvažnije da shvate što se tu sve nudi, a to je ciljana skupina (lokalne jedinice), te krajnji korisnici (građani i poslovni subjekti), posebice oni u najmanjim lokalnim jedinicama koje bi od kvalitetne 
provedbe Plana mogle imati najviše koristi. Stoga je dobro što Plan predviđa, primjerice, terenska ispitivanja, edukacije i slično, što je sve neophodno dobro isplanirati, u što ranijim fazama, s konkretnim rokovima i zadatcima. Dobro je što će se osnivati međuresorne skupine, neophodne za odvijanje takvih planova i projekata, no za bolje informiranje i edukaciju ciljane skupine, kao i krajnjih korisnika, valjalo bi angažirati i druge čimbenike, primjerice Hrvatsku zajednicu županija (HZŽ), Udrugu gradova (UG) i Hrvatsku zajednicu općina (HZO), koji dobro poznaju probleme i mogućnosti ciljanih skupina.

S tim u vezi, hitno treba prirediti što jasniji i jednostavniji, praktični vodič, svojevrsni priručnik s informacijama o Planu i mogućnostima koje nudi lokalnim jedinicama i koristiti ga za podizanje svijesti, informiranje i uključivanje ciljnih skupina (kako izvršnih, tako i predstavničkih tijela vlasti županija, gradova i općina), krajnjih korisnika (građana, njihovih udruga, poslovnih subjekata), ali i medija (posebice lokalnih) u funkcionalno i stvarno spajanje jedinica.

Takvim bi se dobro osmišljenim i pravodobnim akcijama već spomenuto nezadovoljstvo građana funkcioniranjem i uslugama lokalnih jedinica, pa i nezadovoljstvo samih lokalnih jedinica njihovim financijskim i administrativnim mogućnostima, moglo usmjeriti u njihovo aktivnije angažiranje u rješavanju problema koji ih muče, a koje ni najveće, a pogotovo one najmanje, teško mogu samostalno rješavati: prikupljanje i zbrinjavanje smeća, lokalni i regionalni javni prijevoz, brigu o starijima i nemoćnima i sl. Na taj bi se način bolje mogla iskoristiti i sredstva iz drugih europskih izvora (što i jest jedan od ključnih ciljeva Plana), a moglo bi se i doprinijeti ciljevima održivog razvoja UN-a (također istaknutim u Planu). 
Funkcionalno, pa i stvarno spajanje više je nego neophodno u državi s tako velikim brojem lokalnih jedinica, s pedesetak općina koje broje manje od tisuću stanovnika, s drastičnim razlikama među njima, ne samo po broju stanovnika (najmanja ih ima samo 137, a najveća čak 16.500) već i po prihodu po stanovniku (najniži je 1.700, a najviši čak 27.000 kn) (vidi IJF, 2020). I nije točno da se one nisu voljne mijenjati i popravljati. U razdoblju 2015. - 2021., pod utjecajem aktivnosti Instituta za javne financije, uz podršku Ministarstva financija tim aktivnostima, prosječna proračunska transparentnost svih lokalnih jedinica popravila se s 1,8 na 4,5. Dok je primjerice proračun za građane 2015. objavilo samo 1\% općina, 2021. ga je objavilo čak 80\% (vidi IJF, 2021). Informiranje, promoviranje tema, poticanje, promjene zakona i propisa, sve to mora rezultirati promjenama.

Ukratko, Plan svakako treba pozdraviti jer je ne samo funkcionalno već i stvarno spajanje neminovno. No, poučena bivšim sličnim planovima i projektima koji se nikada nisu uspijevali realizirati, nositelji provedbe bi ovoga puta, odmah na početku, trebali:

- utvrditi čvrste rokove i sustav praćenja provedbe,

- napraviti kvalitetne vodiče, priručnike i upute za informiranje ciljnih skupina i korisnika,

- dodatno angažirati predstavnike HZŽ, UG i HZO, akademske zajednice, lokalnih udruga i medija, posebice na samom početku, ali i kroz čitavo razdoblje provedbe Plana.

Sve to bi moglo itekako pridonijeti naporima nositelja provedbe, odnosno Ministarstvu pravosuđa i uprave, Ministarstvu financija i drugim zaduženim tijelima državne uprave, koji će bez takve 
suradnje „s terenom“ teško moći sami provesti ono o čemu se već desetljećima priča, a nikako da se provede. Sada se, eto, pojavljuje još jedna prilika, koju bi stvarno valjalo iskoristiti.

\section{DODATAK}

\section{Provedba daljnje optimizacije i decentralizacije podupiranjem funkcionalnog spajanja lokalnih jedinica}

\section{Faze}

- Prilagodba propisa vezano za fiskalne poticaje za dobrovoljno povezivanje jedinica (prosinac 2021.)

- Aktivacija osnovnog (fiskalnog) mehanizma podrške za dobrovoljna funkcionalna i stvarna povezivanja jedinica (ožujak 2022.)

- Izrada smjernica/preporuka za zajedničko izvršavanje pojedinih poslova i stvarno spajanje jedinica na temelju dobrih praksi EU (prosinac 2023.)

- Uspostava cjelovitog sustava podrške funkcionalnom i stvarnom povezivanju jedinica (lipanj 2025.).

\section{Podfaze}

- Izrada upitnika za jedinice o samoprocjeni kapaciteta trenutnog obavljanja poslova iz svojeg djelokruga i iskazivanju potrebe i interesa za zajedničko obavljanje poslova, odnosno stvarno spajanje

- Utvrđivanje stanja obavljanja poslova iz djelokruga jedinica, koristeći IT sustav, katalog i kategorije izrađene u okviru Optimizacije sustava lokalne i područne (regionalne) samouprave

- Izrada idejnog rješenja i funkcionalne specifikacije Sustava podrške stvarnom i funkcionalnom povezivanju jedinica

- Izrada modela za funkcionalno povezivanje jedinica i utvrđivanje dodatnih financijskih poticaja za stvarna spajanja

- Identificiranje jedinica za koje bi bilo korisno da se funkcionalno povežu te poslova koje bi one mogle zajednički obavljati

- Identificiranje jedinica za koje bi bilo korisno da se stvarno spoje 
- Razvoj i implementacija Sustava podrške stvarnom i funkcionalnom povezivanju jedinica lokalne samouprave (Izrada arhitekture i programskog dizajna, razvoj modula Sustava, implementacija Sustava na infrastrukturu CDU-a, testiranje te izrada korisničke i tehničke dokumentacije Sustava)

- Nadogradnja na IT sustav Optimizacije sustava lokalne i područne (regionalne) samouprave

- Provođenje pilot projekta funkcionalnog povezivanja i stvarnog spajanja

- Edukacija službenika tijela države uprave koji će pružati podršku službenicima jedinica vezano uz funkcionalno povezivanje i stvarno spajanje

- Pružanje digitalne i izravne podrške službenicima jedinica koje zajednički obavljaju poslove ili se namjeravaju stvarno spojiti

- Edukacija službenika jedinica za rad u Sustavu.

\section{Usluge koje će se financirati iz predviđenog proračuna}

1) Savjetodavne usluge za:

- Dijagnostičko izvješće o pravnom i institucionalnom okviru za funkcionalno spajanje jedinica u Hrvatskoj, s uključenim pregledom rezultata u provedbi sličnih reformi u zemljama članicama EU

- Provedbu terenskog ispitivanja stanovništva vezano za funkcionalna spajanja jedinica - ispitivanje i analiza mogućnosti i potreba korisnika javnih usluga za objedinjenim funkcijama

- Razradu modela dobrovoljnog spajanja s kompenzacijskih mehanizmima

- Strategiju provedbe i upravljanja izmjenama s analizom troškova i koristi

- Podizanje svijesti o funkcionalnom spajanju jedinica

- Pripremu i provedba programa izobrazbe za javne službenike uz razvoj „elearning" materijala, edukaciju 50 službenika tijela državne uprave za pružanje podrške jedinicama lokalne samouprave vezano uz funkcionalno povezivanje i stvarno spajanje te edukaciju 100 službenika jedinica lokalne samouprave za obavljanje zajedničkih poslova u okviru funkcionalnog povezivanja

- Vrednovanje implementiranog procesa u smislu učinkovitosti, zadovoljstva i povjerenja građana i preporuke za prilagodbu

- Vrednovanje u tijeku provedbe Nacionalnog plana za razvoj javne uprave 2021. 2027.

- Izradu funkcionalnih zahtjeva za IT sustav podrške funkcionalnom spajanju na temelju modela. 
2) Uspostava IT sustava i softwareske podrške funkcionalnom i stvarnom povezivanju jedinica - izrada arhitekture i programskog dizajna, razvoj modula sustava, implementacija sustava na infrastrukturu CDU-a, testiranje i izrada korisničkih uputa, priprema i provedba programa izobrazbe uz razvoj „e-learning" materijala

3) Komunikacija i uvođenje inovativnih (digitalnih) mehanizama za sudjelovanje građana u provedbi Nacionalnog plana za razvoj javne uprave 2021. - 2027.

4) Upravljanje projektom

Izvor: NPOO, str. 545-546. 